\section{IJIKMMENA}

\section{1,2}

161

\title{
DO SUBSIDIES INCREASE THE POOR'S ACCESS TO FOOD? A CASE OF INFORMATION FAILURE IN EGYPT
}

\author{
Randa Hamza' \\ The American University in Cairo (AUC), Egypt \\ Shadwa Zaher ${ }^{2}$ \\ The British University in Egypt (BUE), Egypt
}

\begin{abstract}
Purpose: The purpose of this paper is to investigate the Egyptian government's subsidisation policies in the wheat sector. The paper argues that it is essential to develop knowledge- and data-management tools to better understand the market and create informed decisions. It examines the different policies that will secure the sector from future shocks through information-management tools. The paper also demonstrates how these tools improve national policies and enhance the self-sufficiency and accessibility of the poor.

Design/methodology/approach: The paper uses descriptive analysis to show production and consumption trends as well as the effects of wheat subsidies from 2005 to 2010.

Findings: The analysis concludes that subsidies should be maintained by only targeting the poor through a better utilisation of knowledge and information to prevent any leakage. In addition, policies that increase rural farmers' local production and competitiveness need to be introduced to avoid any kind of future supply shocks.
\end{abstract}

International Journal of Innovation and Knowledge Management in Middle East \& North Africa Vol. 1 No. 2, 2012
${ }^{1}$ Randa Hamza, The American University in Cairo (AUC), AUC Avenue, P. O. Box 74, New Cairo 11835, EGYPT.

${ }^{2}$ Shadwa Zaher, The British University In Egypt (BUE), El Sherouk City, Cairo, Postal No. 11837, P. O. Box 43, EGYPT. 
Research limitations/implications: The limitation is the absence of enough data during the period between 2009 and 2012. Methods of estimation were used to avoid this problem.

Originality/Value: Many scholars have researched policy reforms in the wheat sector but few have addressed the major deficiency in information management that negatively affects any attempt to restructure the sector. The results lead to the conclusion that subsidies need to be shifted to wheat inputs.

Keywords: Wheat; Egypt; Policy Distortions; Information; Food access; Food security; Subsidies and Knowledge Management.

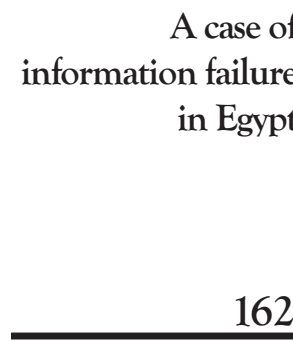

162

\section{INTRODUCTION}

Food security is a vital topic for development. It is a crucial step in achieving a number of Millennium Development Goals. It constitutes a major factor in combating poverty and hunger, in improving health conditions and in achieving environmental sustainability. According to the World Food Summit of 1996, food security is defined as a state when "all people" are physically and economically capable of accessing "sufficient, safe (and) nutritious food (of their preference) to maintain a healthy and active life". In a rapidly globalizing world, developing countries are struggling to improve their agricultural sectors, where a high percentage of the population is employed. Meanwhile, they are forced to liberalise their markets and allow for international competition. However, with the increasing threats of global warming and food shortages, developing countries as well as international organizations are re-examining the proper policies to achieving food security.

The above-mentioned definition of food security sets out three criteria for its fulfillment; namely: availability, access and nutritional value. These criteria, under free trade theories, assume that countries that have surpluses in major nutritional food staples would always be willing to trade these 
IJIKMMENA surpluses with developing countries that suffer from short1,2 ages at affordable prices. In reality, there may be a number of constraints in applying this hypothesis. Under free market forces, international and national distribution dynamics do not guarantee that major nutritional food staples go to the poorest and neediest people. Moreover, unprotected national agricultural sectors in developing countries lead to the further impoverishment of their rural communities, whose main occupation is agriculture.

Historically, wheat has been the most important food staple in the world. Its nutritional value as a major inexpensive source of energy and protein makes it also the main food staple for the poor. Influenced by global climate change, the annual production of wheat has suffered fluctuations, causing price instabilities affecting many countries around the globe. The poor have been the most influenced by the price and quantity volatility in the international wheat market.

Egypt is the world's biggest wheat importer, with 9.8 million metric tons imported according to the United States Department of Agriculture's estimates for 2010. Egypt is also one of the countries with the highest per capita consumption of this particular food staple. This creates an alarming situation for the Egyptian consumer's vulnerability to the changes in the international wheat market. Therefore, the Egyptian government committed to wheat subsidisation policies to enhance access for the poor. It also increased the local retail market price of wheat to international market levels to encourage local farmers to increase production and improve the country's self-sufficiency ratio.

Although local production increased substantially during the period from 1998 to 2004, the prevailing system was highly favourable to urban consumers while putting farmers and 
rural inhabitants at a great disadvantage (Nino, Krenz and Siddik, 1998). Moreover, several leakages occurred that led to the inefficient allocation of factors of production and government resources.

This paper argues that in order to improve the country's self-sufficiency ratio, knowledge-management processes need to be more effective. They should be equipped with policy tools to ensure that subsidies reach those who deserve them and to avoid leakage. The paper also suggests that subsidisation of wheat inputs needs to be considered to encourage farmers to increase local production.

The paper is divided into three sections. Section one presents an overview of the current wheat market situation in Egypt. Section two analyzes the effects of recent policy reforms on the flow of knowledge assets in the wheat sector that create several distortions affecting three main entities, namely; the consumer, the farmer and the private sector. The third section then presents alternative solutions to remove market distortions and overcome the knowledge gap that will enhance both the consumers' and the producers' behaviours. Finally, the paper concludes with the recommendations and policy reformulations that would better target the poor and encourage domestic production.

\section{OVERVIEW OF THE CURRENT SITUATION}

Egypt's vulnerability comes from indigenous as well as exogenous factors. As mentioned earlier, Egypt's per capita consumption of wheat is one of the highest in the world. This is attributed to a number of factors. First, the continuous increase in population and its impact on the increased demand for food. Second, the government's bread subsidies, which make its end price almost 66 per cent lower than the market 
IJIKMMENA price, leaving bread the ultimate cheapest source of protein 1,2 and energy for the poor (Abdellatif, Kherallah and Gruhn, 1998). Third, the rising inflation in food prices, especially in the last two years (CIA World Factbook), encouraged consumers to substitute other food products for subsidised bread. Due to the low price of bread, peasants also use it as feed for farm animals (Abdellatif et al., 1998). Finally, rural-urban migration increases the urban poor's demand for subsidised bread.

As for the exogenous factors, they are attributed to the fact that the Egyptian wheat market is highly dependent on wheat imports to fulfill its domestic production and consumption needs, as shown in Table 1. During 1998, Egypt had to import more than 40 per cent of the wheat consumed in the country (CAPMAS, 2001). In 2009/10, Egypt imported 7.1 per cent of global wheat imports to feed only 1.2 per cent of the global population.

Therefore, any fluctuations in international wheat prices affect the local market dramatically and cause supply shocks (Ibrahim and Ibrahim, 2003). This was evident when Russia, a major wheat exporter to Egypt, experienced droughts and fires in 2010. The Egyptian market was shaken as a result, and food security became an urgent issue.

Alarming reports suggest that the Russian wheat problem is merely an indication of the future instability in international wheat and grain production due to supply shortages, climate change and growing demand in recipient countries. This led a number of exporting countries to issue restrictions or bans on exports to secure their national markets.

As a result, the Egyptian government announced that it will adopt policies to increase local production over the next decade to improve the country's self-sufficiency ratio and 
achieve better food security. In order to achieve the country's targets, an in-depth analysis of current policies and their information failure effects on the levels of production and consumption in the wheat sector needs to be undertaken. The process of managing information between farmers, private sectors and the consumer also needs to be examined.

166

\begin{tabular}{|c|c|c|c|c|c|c|}
\hline Country & $2005 / 06$ & $2006 / 07$ & $2007 / 08$ & 2008/09 & $\begin{array}{l}\text { 2009/ } \\
\text { 10-Dec }\end{array}$ & $\begin{array}{l}2009 / \\
10-J a n\end{array}$ \\
\hline Algeria & 5,476 & 4,874 & 5,904 & 6,359 & 5,300 & 5,300 \\
\hline Bangladesh & 234 & 1,731 & 1,555 & 2,882 & 2,600 & 2,600 \\
\hline Brazil & 5,823 & 7,704 & 7,136 & 6,367 & 6,500 & 6,500 \\
\hline Egypt & 7,771 & 7,300 & 7,700 & 9,900 & 8,300 & 8,800 \\
\hline EU-27 & 6,758 & 5,137 & 6,942 & 7,740 & 70 & 6,500 \\
\hline Indonesia & 4,981 & 5,596 & 5,224 & 5,423 & 5,500 & 5,500 \\
\hline Iran & 1,105 & 700 & 200 & 9,300 & 50 & 4,500 \\
\hline Iraq & 4,996 & 2,912 & 3,424 & 3,868 & 3,800 & 3,800 \\
\hline Israel & 1,663 & 1,458 & 1,186 & 260 & 2,100 & 2,100 \\
\hline Japan & 5,469 & 5,747 & 5701 & 5,156 & 5,300 & 5,300 \\
\hline Korea South & 3,884 & 3,439 & 392 & 3,371 & 3,700 & 3,700 \\
\hline Libya & 1,722 & 994 & 1,567 & 1,677 & 1,650 & 1,650 \\
\hline Mexico & 3,549 & 3,610 & 3,136 & 3,341 & 3,300 & 3,100 \\
\hline Morocco & 2,418 & 1,801 & 4,191 & 3,759 & 1,800 & 1,800 \\
\hline Nigeria & 3,678 & 3,265 & 2,677 & 3,550 & 3,500 & 3,500 \\
\hline Peru & 1,644 & 1,367 & 1,452 & 1,385 & 1,500 & 1,500 \\
\hline Philippines & 2,954 & 2,754 & 2,266 & 3,201 & 30 & 300 \\
\hline Sudan & 1,659 & 1,323 & 160 & 1,712 & 1,500 & 1,500 \\
\hline Tunisia & 1,263 & 1,433 & 2,372 & 1,772 & 1,500 & 1,500 \\
\hline Venezuela & 1,691 & 1,765 & 1,492 & 1,500 & 1,525 & 1,525 \\
\hline Yemen & 2,187 & 2,420 & 1861 & 2,786 & 2,300 & 2,300 \\
\hline Others & 34,507 & 39,966 & 36,600 & 40,650 & 34,205 & 35,240 \\
\hline Subtotal & 108,846 & 110,250 & 110,517 & 135,936 & 117,780 & 118,115 \\
\hline Unaccounted & 2,684 & 1,952 & 2,918 & 384 & 2,979 & 2,534 \\
\hline United States & 2,299 & 3,394 & 312 & 3,460 & 3,100 & 3,100 \\
\hline World Total & 113,829 & 115,596 & 116,447 & 142,480 & 123,859 & 123,749 \\
\hline
\end{tabular}




\section{IJIKMMENA}

1,2

\section{ASSESSMENT OF RECENT AND CURRENT POLICIES}

Egypt started introducing agricultural reforms in 1987. The Egyptian wheat and flour economy is roughly structured into two distinct subsectors: a private sector and a public sector. The private sector is only allowed to process imported wheat to produce unsubsidised bread and flour. The public sector, however, mainly processes local wheat to produce subsidised Baladi bread and flour. This division does not favour local Egyptian farmers, since they lack access to the more profitable and competitive private market and are only allowed to operate through official government channels (Nino, Krenz and Siddik, 1998). In addition, this system hinders the potential of private mills to compete and make profit in a free and dynamic market.

The Egyptian agricultural system started to be partially liberalised in 1987 and continued to undergo more reforms during the following two decades. The government permitted increased competition within the sector and liberalised the Fino flour by the beginning of 1992. Free markets were opened for the sale of Fino flour and bread. In 1993, all the remaining restrictions on Fino flour production and trading were removed (Adams, 2000).

Restrictions over the exchange and sales of bran and wheat prices were relaxed. Therefore, during the period of 1991 to 1996, both the consumption and production of grain and flour imports increased. By the end of 1997, nine new private mills were allowed to operate alongside the already existing public mills (ibid, 2000). In addition, the government offered farmers higher prices for their produced wheat.

These reforms had a number of significant advantages for local production. The wheat area plant was doubled and 
yields increased by 48 per cent. In addition, wheat production almost tripled (Kherallah et al., 2000). This rise in production between 1996 and 2000 led to a considerable improvement in the wheat self-sufficiency ratio from 21 per cent in 1986 to 47 per cent in 1996.

However, higher demand endured and imports increased from 6 to 7 million tons per year. The gap between the imported wheat and domestic production also grew between 2007/2008 and 2009/2010, as shown in Table 2. Moreover, the government continued its control and intervention in most of the exchange and sale activities in the sector.

During the period between 1998 and 2004, the operating system was highly biased towards urban consumers while placing farmers and rural inhabitants at a great disadvantage. This did not, in fact, achieve the government's main aim of the heavy subsidisation of the sector, which was to secure the access of lower-income consumers to a strategic good.

\begin{tabular}{|c|c|c|c|c|}
\hline Wheat & $2007 / 2008$ & 2008/2009 & $2009 / 2010$ & \\
\hline Production & 8,275 & 7,883 & 7,864 & \\
\hline Imports & 8,310 & 8,320 & 8,325 & \\
\hline Imports from US & 2,404 & 2,350 & 2,360 & \\
\hline $\begin{array}{l}\text { Total } \\
\text { Consumption }\end{array}$ & 16,562 & 15,970 & 15,934 & \multirow{2}{*}{$\begin{array}{l}\text { Table 2: } \\
\text { Egyptian wheat } \\
\text { production, imports } \\
\text { and consumption }\end{array}$} \\
\hline $\begin{array}{l}\text { Source: USDA, Foreign } \\
\text { Service }\end{array}$ & ricultural & & & \\
\hline
\end{tabular}

A case of information failure in Egypt 168 
IJIKMMENA

1,2

\section{DISTORTIONS OF CURRENT POLICIES}

The current policies adopted by the government have significant distortions that negatively affect the consumer, the farmer and the private sector as follows:

\section{For Consumers}

As mentioned above, the government's main objective for bread subsidies was to provide an affordable nutritional food staple to the poor and protect them from international market price instabilities. Therefore, it kept the wheat market under state monopoly with regards to Baladi bread, which is considered to be the preference of the poor (Abdellatif, Kherallah and Gruhn, 1998). Accordingly, public mills became the main producers for Baladi subsidised bread. However, the government did not tailor specific distributional policies to target the poor.

Therefore, a considerable percentage of the subsidies leaked to urban middle and upper class consumers. This could have been avoided if the public authorities had invested in data collection and information management to enable the government to better address the targeted groups with its subsidies. Consequently, due to the failure to gather and utilise essential information, a very costly subsidy has been operating for years with little effect in providing better nutrition to the poor.

\section{For Farmers}

In an attempted plan to move towards self-sufficiency in local 
production of wheat, the government increased its reliance on locally produced wheat to cover its needs for the production of Baladi bread. It therefore increased the price at which it purchased wheat from local farmers. This, along with the introduction of high yielding seeds and modern irrigation technologies, encouraged farmers to grow more wheat, which increased the country's self-sufficiency ratio from 21 per cent in 1986 to 47 per cent in 1996. The rate even hit 59 per cent over the period from 2001 to 2003 (Croppenstedt, 2005) before declining to approximately 55 per cent in 2010 .

After the significant decline in recent years and the shock the country's food security encountered due to the wheat shortage in 2010, the government announced a target of 70 per cent self-sufficiency to be achieved over the next decade.

However, in adopting more liberal policies in the agricultural sector, many input subsidies to farmers were removed in order to shift the agricultural sector into a more market-oriented model. This resulted in a considerable increase in production costs for farmers. Government policies failed to create the market incentive that would encourage local farmers to achieve the national plan. The rational behaviour of farmers was a reaction to the basic market information they acquired. They responded to the increase in the cost of production and the ceiling on the market price by exiting the market.

Meanwhile, in major wheat exporting countries in Europe and North America, governments adopt protective policies to their agricultural sectors so that farmers receive considerable subsidies in major crops, including wheat. This greatly distorts the international market price for wheat. However, the Egyptian government purchases local wheat from farmers at a price equivalent to that of the international market, yet does not provide the farmers with equal subsidies. This creates a

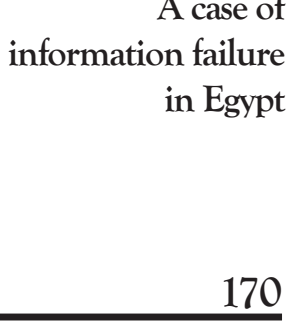


IJIKMMENA repellent environment for local wheat plantation.

\section{1,2}

\section{For the private sector}

About 90 per cent of the land cultivated with wheat is owned by small- and medium-scale farmers. With limited financial resources, disguised unemployment and primitive irrigation methods, the productivity of the wheat sector is measured as 20 per cent less than the efficient level (Croppenstedt, 2005).

The introduction of private investors into the wheat market created possibilities for generating new dynamics in this sector. Andre Croppenstedt (2005) argues that large-scale investments in the sector, and specifically, increases in land area have the highest effect on increasing output. He estimates that a 1 feddan increase in land results in a 44 per cent increase in output. Yet the monopoly and control of the government over locally produced wheat discourages large investors and businessmen from entering this sector and thus discourages significant increases in wheat plantation land and wheat production. This is another area where knowledge management has simply failed in Egypt.

The persistence of the State monopoly has provided no incentive to the private sector to venture in sizable investments in the sector. There is no proper channel through which policy makers are able to understand the constraints and opportunities the private sector could offer. In addition, local producers are only allowed to sell their crops to the government, limiting their profitable opportunities compared to those they would enjoy if they could sell to the private sector. According to free market dynamics, private mills can offer farmers higher prices than those offered by the government. They also provide small farmers with credit loans for the plantation season, which alleviates some of the hardships 
the farmers experience due to increased input prices. Finally, private buyers collect the crop from the farms, releasing them from the transportation costs they incur when they deliver to public mills. However, as mentioned above, the private sector is only allowed to import its needs from foreign markets and is banned from purchasing local wheat.

In short, there is a dearth of information relating to the distribution and qualifying status of the consumers in regard to the subsidy, no effective data on the farmers or their knowledge and experience and very little opportunity to share information between the private sector and the policy makers. In this environment, any application of knowledge-management tools and processes is almost doomed to failure, even though such methods can be highly effective. But in the absence of the most basic data inputs it is very unlikely that the sector will benefit from any applications in knowledge management, despite the fact that it seriously requires such tools.

\section{ALTERNATIVE SOLUTIONS}

As mentioned before, the system of current subsidies is urban-biased and there is no fairness in the distribution of the subsidised bread. Two main factors are responsible for this inequitable system. First, the government sells a higher percentage of the subsidised 82 per cent wheat flour in Cairo and Alexandria, where most of the beneficiaries are of middle- and higher-income levels and hence are not the targets of the subsidies. A standardized effective policy followed by a number of developing countries is, therefore, to apply rationing coupons so that a certain quota of subsidised bread is distributed solely to lower-income citizens. This ensures that the goal of the subsidies is achieved. This policy will also gradually rationalise both quantities and prices, which will alter the patterns of increased consumption to lower levels. But for this information failure in Egypt 
IJIKMMENA 1,2 to work effectively, the government needs to collect and effectively manage a wide range of data.

Some economists argue that the government might not be able to reach all the neediest citizens; Abdellatif et al. (1998) therefore suggest that one option is to distribute subsidised bread to poor children in schools. This will ensure that children receive the sufficient nutritional amounts of the wheat they need in what is referred to as the 'Food for Education' programme. In addition, one of the recommended policies is to adopt a 'Work for Food' programme for the lowest-paid workers. This could be applied through the private sector as a social corporate responsibility measure that will also enhance the health and nutrition conditions of the poor. Yet again, for these policy tools to be effective, extensive research and data collection need to be completed first to allow policy makers to pinpoint the target groups and monitor the implementation process and evaluate its effectiveness.

The restrictions of the government on local wheat and private mills cripple significant further developments to this sector. However, as the government's target is to increase the local production of wheat over the next decade to achieve a higher self-sufficiency ratio, it should stimulate more private investments and address the distortions that currently operate. Therefore, wheat plantation needs to become a considerably more profitable business for farmers.

This could be achieved through redirecting subsidies towards the inputs of production specific to this crop, such as fertilisers and pesticide. Such an approach requires basic information that is easy to acquire and hence is likely to be more amenable to the application of knowledge-management tools. Meanwhile, the price of the end product should be freed to market forces, allowing the private mills and bread producers 
to purchase wheat from local farmers. These two factors together help stimulate farmers to prefer wheat production as it would incur lower costs and a higher selling price, which will ultimately increase profitability.

Similarly, private mills should be allowed to produce Baladi bread and sell it at market prices in urban areas. This will establish a market price for Baladi bread for both middleand higher-income consumers, who currently enjoy a subsidy. It will also reduce the government's burden to supply large quantities of Baladi bread to urban consumers.

\section{CONCLUSIONS}

Wheat is the most vital food staple in Egypt. This is reflected in the country's high per capita consumption levels that are almost double the international averages. As the world's highest importer of wheat, Egypt has become significantly dependent on foreign markets. Although it adopted agricultural reform policies in 1987 that directly increased the local production of wheat, the country continued to experience increasing demands on wheat imports. This situation threatened the country's food security when Russia, a main exporter to Egypt, banned its exports due to fires and droughts.

As a result, the government announced its intention to increase the local production of wheat and thus the self-sufficiency ratio, to avoid future shocks. However, the government needs to revisit the current policies with regards to the wheat sector and apply a number of modifications to achieve these targets. The main issues it needs to address are policies that should enhance production and rationalise consumption through ending the state monopoly of this sector.

The policies needed to enhance production are those

\section{A case of information failure in Egypt}


IJIKMMENA directed towards farmers and private mills. In order to encour1,2 age more investments in wheat plantation, this crop needs to be significantly profitable to farmers. This can be achieved through government subsidisation to input factors, which will minimize the cost to farmers. This requires less data than that needed for targeting qualifying consumers and hence is more likely to be successful. Meanwhile, farmers should be allowed to sell their crops to the private sector. Private mills should also be permitted to process and sell the state monopolized Baladi bread in urban markets to middle- and higher-income consumers.

As for the policies that ought to rationalise consumption, they need to be directed properly in order to avoid subsidy leakages. Ration coupons aimed at the lowest-income consumers could be introduced to ensure the efficiency of those subsidisation measures that, under the current policies, are biased towards urban middle- and high-income groups. However, the ration coupons require detailed information on consumer geography and incomes and the authorities need to invest in gathering this information so as to make the policies more effective. The government can also introduce other social-oriented subsidy policies such as Food for Education and Food for Work programmes through corporate social responsibility programmes by the business sector.

Last but not least, by following a comprehensive rather than partial liberalisation reform system for the whole wheat sector, the fruits of the reform would be more effective. Even in this case a subsidy will still be required, and its implementation will necessitate the correct management of information. Only if the latter is actually collected and built into a proper knowledge-management system will the efficiency of the subsidy policies be improved. 
A case of

Randa Hamza is a researcher in the Economic and Business information failure History Research Center at the American University in Cairo. She earned her Master's degree with highest Honours in Economics in International Development at the American University in Cairo. She finished her undergraduate studies with Honours at the School of Economics at the American University in Cairo, Majoring in Economics and acquiring a Minor degree in International Relations. Randa has specific interest in development policies and the role of planning in developing countries. She has contributed a number of research projects to the field, some of which include the experience of micro credit organizations in Egypt, the effects of foreign aid on the development of emerging economies and the analysis of the Egyptian industrialisation and privatisation policies.

Shadwa Zaher is an assistant lecturer at the Economics department at the British University in Egypt. She finished her Master's degree in Economics in International Development with highest Honours at the American University in Cairo. She graduated from the Faculty of Economics and Political Science, Cairo University, Majoring in Economics and acquiring a Minor degree in Public administration. She published a paper on the "Demand for Military spending in Egypt" in the discussion papers, Department of Economics, University of the West England, Number 1001. She won several awards and scholarships; one recent award was the second best coauthored paper in the Annual Conference of the Economic Forum of Entrepreneurship \& International Business. She researched several topics on Macroeconomic policies and Development economics. She is now working on her $\mathrm{PhD}$ research proposal on the effect of competitiveness on the structural reform of the Egyptian economy. 


\section{IJIKMMENA}

\section{1,2}

\section{REFERENCES}

Abdellatif, A., Kherallah M. and Gruhn P. (1998), "Wheat Policy Reform in Egypt: Effects on Production, Prices and Marketing Channels", Development Policy Review Vol. 16. pp. 227-240.

Adams, R. H. (2000), "Self-Targeted Subsidies: the Political and Distributional Impact of the Egyptian Food Subsidy System”, Chicago Journals Vol. 49 No.1, pp.115-36.

Croppenstedt, A. (2005), "Measuring Technical Efficiency of Wheat Farmers in Egypt", The Agricultural Development Economics Division (ESA) is the focal point for FAO's economic research and policy analysis for food security and sustainable development, Egypt.

Ibrahim, F.N. and Ibrahim, B. (2003), "Egypt: an Economic Geography”, International Library for Human Geography.

Kherallah, M., Lofgren, H., Gruhn, P. and Reeder, M.M. (2000), "Wheat Policy Reform in Egypt: Adjustments of Local Markets and Options for Future Reform", International Food Policy Institute (IFPRI), 115th series.

Nino, E.A., Krenz, R. and Siddik, I. (1998), "The Wheat Sector in Egypt: Policy Implications”, Chicago Journals. Rpt. in Research Development Institute. Series 10. 
